\title{
SHIFTING OF LAND USE IN SUSTAINABLE TOURISM: A LOCAL CULTURAL APPROACH IN INDONESIA
}

\author{
WARIDIN* \\ Diponegoro University, Faculty of Economics and Business, Semarang, Central Java, 80331, Indonesia, e-mail: waridin.dr@gmail.com
}

I Putu ASTAWA

State Polytechnic of Bali, Tourism Department, Bukiti Jimbaran, Bali, 80361, Indonesia, e-mail: putuasawa1@pnb.ac.id

Citation: Waridin, \& Astawa, I.P. (2021). SHIFTING OF LAND USE IN SUSTAINABLE TOURISM: A LOCAL CULTURAL APPROACH IN INDONESIA. GeoJournal of Tourism and Geosites, 35(2), 270-274. https://doi.org/10.30892/gtg.35201-647

\begin{abstract}
Tourism becomes a hotly discussed topic because it has a significant impact on the economy, social, and culture. This study analyzes changes in yard land use to support sustainable tourism based on local culture, namely the culture of harmony. This research was conducted through two approaches. The first was carried out qualitatively to see changes in depth in the use of Ubud community yards. The second is done quantitatively with the help of statistics to determine the impact of these changes. Data were collected through in-depth interviews with people who own land changes and through questionnaires. The selection of informants was based on recommendations from the traditional village leadership using the snowballing method. A total of 38 land owners have filled out the questionnaire correctly. The results of the qualitative research explained that most land-use changes were in palemahan Or teba, which were initially used as a breeding place, remove dirt, and gardening functioned as a place to stay for tourists. The quantitative results explain that land changes based on a culture of harmony have a positive impact on the economy, social, culture, and environment. The results of this study support the development of sustainable tourism which is an important issue in today's era.
\end{abstract}

Key words: land, culture, sustainable tourism, Ubud

$* \quad * \quad * \quad * \quad * \quad *$

\section{INTRODUCTION}

Sustainable tourism is an issue that is very interesting and is still being debated today. Various impacts of climate change on tourism practices are increasing (Becken and Hay, 2007; Gössling and Scott, 2008) and sustainability is also increasingly important in running a tourism business (Font and Harris, 2004; Murphy and Price, 2005; Swarbrooke, 1998; Weaver, 2006). Sustainable tourism includes environmental, economic and socio-cultural responsibilities (Kapera, 2018). These three responsibilities are the basis for building green tourism, requiring all tourism industry players such as tourists, companies, communities, and government to be actively involved (Sadguna et al., 2020; Astawa, 2018e; Liu et al.,2017). The involvement of stakeholders in various countries in implementing the green concept is still diverse. This is influenced by several factors, such as various economic, socio-cultural, political and security factors (Mika, 2015).

The results of the study provide an explanation that socio-cultural factors are very important in developing destination areas that have cultural orientation (Mika, 2015; Astawa et al., 2018a) and other factors such as economic factors and environmental factors are also taken into account in sustainable tourism (Schönborn et al., 2019). Several countries view the tourism industry as a good way to increase the economy and job vacancies (WTO, 2016). However, many also sacrifice natural, site or cultural resources for the benefit of tourists (Blancas et al., 2018). This negative impact encourages the issue of sustainability is very important to do so that the target of tourist satisfaction does not sacrifice existing resources and culture. Indonesia is a developing country that has famous tourist attractions in the world such as Ubud, where culture is the cornerstone of tourism. When culture is recognized as a product in the tourism industry, it will raise new challenges from all organizations involved in the tourism industry (Bradley, 2018). The vision and mission of the organization or company management must adapt to the existing environment and culture (Piketty, 2014). The adjustment of local culture into organizational culture is a new challenge that must be considered because there will be friction between internal and external interests related to existing cultural values so that sustainable tourism goals cannot be achieved (Agyeiwaah et al., 2017).

Culture influences management practice (Rajiani and Pyplacz, 2018). The core element in culture is the value in which the relationship between humans in a society is always influenced by the values that are part of the collective program of people's minds (Hofstede, 2007; Ranasinghe, 2019; Wróblewski and Kasperek, 2019). In Ubud, the foundation of shared beliefs and values is the Tri Hita Karana (three causes of happiness/THK) philosophy which transcends all aspects of life, including business and governance. THK philosophy profoundly influences social values, attitudes, and norms in the Ubud tourism system and its deep relationship with the natural environment which is deeply rooted in this belief system (Rahmawati et al., 2019; Sukawati and Astawa, 2017). The belief system of the people of Ubud related to the natural environment or residential land is divided into three parts, namely the main part, the middle part, and the back part or refe rs to the asta kosali culture or building layout, where the building for worshiping God is placed at the top (upstream), then followed by a building for mutual or middle interaction, and finally or tebe used for a garden, pen, and garbage disposal 
(Rahmawati et al., 2019; Sukawati and Astawa, 2017). The results of the data show that in Ubud, the average household has three or four rooms for rent to guests (Sukawati and Astawa, 2017). Based on this phenomenon, this study analyzes changes in the use of community yards for sustainable tourism purposes in which there are cultural values that must be preserved. This research model has not been widely used and most of the approaches are economic (Rahmawati et al., 2019).

\section{MATERIALS AND METHODS}

This study uses two approaches, namely qualitative and quantitative (Creswell and Clark, 2017; Astawa et al., 2019d). In the qualitative stage, an in-depth interview was conducted with the owner of the yards who had changed in Ubud. Prior to the interview, a letter was first sent via email and post which contained a discussion regarding the concept of changing the use of the yard that had been developed based on the Astakosali culture (Astawa et al., 2018a). A total of nine people who were representatives of each community as informants had provided a detailed and clear view of the changes in yard use and the average interview length was 65 minutes. The selection of these nine informants was based on recommendations from Bendesa. The data collected is compared with existing theories (Glaser and Strauss, 2017) and coding was done using Miles and Huberman (1994). Qualitative results are used to make a questionnaire with five Likert scales which consists of three aspects, namely aspects of God, aspects of human, and natural aspects (Astawa et al., 2018a) and have been tested to determine the validity and reliability of 30 household heads and the results are valid and reliable.

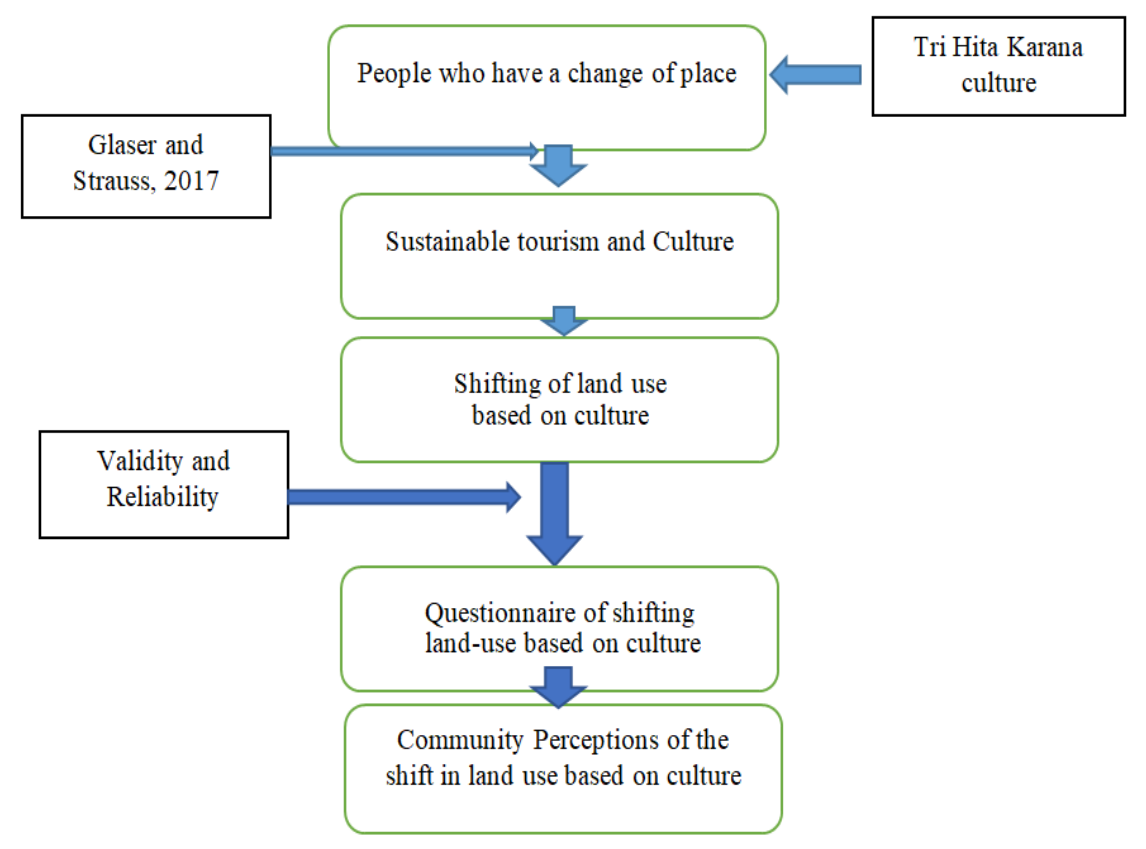

The quantitative stage is carried out starting with sending a questionnaire via email and post to the head of the household whose data is provided by the tourist village as many as 82 people. The collected data will be analyzed with descriptive statistics (Sugiyono, 2010).

\section{RESULTS DISCUSSIONS}

The reality of the use of Balinese customary land, as reported by the national news site vivanews.co.id, states that in 2012 the conversion of land in Bali reached 3,400 hectares. This means that the average land use conversion on the Island of the Gods is more than 3 hectares per day. Conversion of land functions cannot easily be prevented, especially in private land ownership, but the same phenomenon also occurs with customary land, even though it is still under the control of Pakraman village.

Figure 1. Methodology Design (Source: Creswell and Clark, 2017; Astawa et al., 2019d)

But this reality then puts the hope of maintaining Balinese land in general in the Pakraman village community organization through its original authority with autonomy which can manage its own household. To be able to describe the use of customary lands in Bali based on the results of research in areas where development dynamics are rapidly developing and the impact of tourism is very strong, namely in the village of Pakraman Ubud and the village of Pakraman Jimbaran. There are differences in these areas, the main picture is in tourist areas, the use of customary land in tourism destination areas seems to have shifted its function, like in the village of Pakraman Padang Tegal Ubud, Gianyar.

Local customary lands have experienced a shift in function, which was originally intended for boarding houses, the village yard land has been widely used as well as places for tourism support businesses such as homestays, art shops, cafes, and others. The results of qualitative research on land shift seen from culture can be explained in the Table 1.

Based on the explanation in table 1 that the sanctity of a place of worship towards God is still well preserved, and gives the belief that what is in this world is a creation, so that gratitude is manifested in preserving the values and functions of buildings in accordance with the legacy of their ancestors. The belief in the greatness of God gives the people of Ubud the strength to innovate in maintaining tourism that is integrated with religion. Maintaining cultu ral values that still maintain harmonization of the relationship with God, harmonization with humans through the provision of a place that is located in the middle, and harmonization with nature utilizing Tebe space are very much in line with sustainable tourism (Astawa et al., 2019d). The most changes in land use were in palemahan tebe, where it was initially used as a breeding place, throw dirt, and gardening functioned as a place to stay for tourists which are arranged like a villa that blends with nature. The concept of this building is in line with sustainable tourism which supports the creation of a beautiful environment (Kimbu and Tichaawa, 2018). This concept is an innovation in developing a community-based tourism concept to maintain business sustainability (Putri et al., 2020; Sumarmi et al., 2020). The results of distributing questionnaires to tourism village managers show that $66 \%$ of tourism village managers have a bachelor's education and the rest have high school education. The average length of serving as head of the tourism village management is 3 years and has an average age of 47 years as 
much as $75 \%$ and the rest of the age is 48 years and over. Judging from the education of the managers, it is very adequate in carrying out the concept of management in the village and is also supported by a very productive age, so that the concept of developing yards in tourist villages has the opportunity to run well.

Table 1. The meaning of land use from cultural concepts

\begin{tabular}{|c|c|c|c|}
\hline Informant & Divinity/Parahyangan (Upstream) & Human/Pawongan (Middle) & Nature/Pelemahan (Tebe) \\
\hline Informant. 1 & The shrine for the ancestors is still the same as before & Place of communication with family & $\begin{array}{l}\text { The garbage dump has been } \\
\text { managed by the village }\end{array}$ \\
\hline Informant. 2 & $\begin{array}{l}\text { Our family temple is well maintained and } \\
\text { ceremonies are carried out regularly }\end{array}$ & $\begin{array}{l}\text { Maintain communication with family } \\
\text { and outsiders }\end{array}$ & $\begin{array}{l}\text { The cost of land and the demand } \\
\text { for guest accommodation is } \\
\text { increasing, so I use it for rooms }\end{array}$ \\
\hline Informant. 3 & $\begin{array}{l}\text { Do not dare to dismantle despite many requests from } \\
\text { guests }\end{array}$ & $\begin{array}{l}\text { ay with us interact in } \\
\text { e }\end{array}$ & $\begin{array}{l}\text { No longer have tebe like before, } \\
\text { I pack it like a villa for guests }\end{array}$ \\
\hline Informant.4 & $\begin{array}{l}\text { Ancestral legacy in the form of merajan (family } \\
\text { prayer place) still remains }\end{array}$ & $\begin{array}{l}\text { d space to communicate } \\
\text { ther }\end{array}$ & $\begin{array}{l}\text { I have arranged the slum Tebe } \\
\text { into a beautiful garden }\end{array}$ \\
\hline Informant.5 & I keep a sacred place well & $\begin{array}{l}\text { This place is often referred to as } \\
\text { menyame beraye (for relatives who } \\
\text { come to the house) }\end{array}$ & $\begin{array}{l}\text { Tebe still exists } \\
\text { in the form of a } \\
\text { longer for throv }\end{array}$ \\
\hline Infor & $\begin{array}{l}\text { prayer place because it is fo } \\
\text { Ubud people }\end{array}$ & $\begin{array}{l}\text { Intent interaction between guests and } \\
\text { household members }\end{array}$ & Used for buildings such as villas \\
\hline Informant.7 & $\begin{array}{l}\text { Ire born because of God and we should } \\
\text { d worship Him through the family temple }\end{array}$ & lings occurs in the & $\begin{array}{l}\text { I made a bungalow for the tebe } \\
\text { land }\end{array}$ \\
\hline Informant. 8 & $\begin{array}{l}\text { The concept of culture } \\
\text { head that should be gua }\end{array}$ & $\begin{array}{l}\text { uman relationships } \\
\text { resentative place }\end{array}$ & $\begin{array}{l}\text { Tebe becomes the belle now in } \\
\text { Ubud for making dollars }\end{array}$ \\
\hline Informant.9 & $\begin{array}{l}\text { The concept of c } \\
\text { parahyangan is a }\end{array}$ & humans need a pl & $\begin{array}{l}\text { The concept of slum and dirty } \\
\text { has now changed its function } \\
\text { as a residence }\end{array}$ \\
\hline Conclusion & $\begin{array}{ll}\text { - } & \text { A sacred place } \\
\text { - } & \text { There is no change in function } \\
\text { - } & \text { Well taken care of } \\
\text { - } & \text { Trust and belief in the greatness of God }\end{array}$ & $\begin{array}{l}-\quad \text { A place to communicate with } \\
\text { fellow humans } \\
-\quad \text { Having a relationship } \\
-\quad \text { Serving guest } \\
-\quad \text { Maintaining a relationship }\end{array}$ & $\begin{array}{l}\text { - A place for guests to stay } \\
\text { - As a garden } \\
\text { - Villa or bungalow } \\
\text { - The impression is rundown } \\
\text { and dirty does not exist }\end{array}$ \\
\hline
\end{tabular}

Higher education has a deeper ability to solve various problems (Dwi Atmanti, 2005). Activities related to the use of the yard which consist of activities for divinity, for living quarters, for guest houses, and for gardens. This condition is explained by the perception that has an average value of 4.52 and is close to 5 (Table 2) which means agreeing that the activity is carried out in activities to maintain culture and support tourism. The condition that gets high support is the room activity for guests because in the village of Ubud it is synonymous with the most featured homestays. This response is the same as various previous studies where guests feel happy to stay in people's homes (Astawa, 2018e; Astawa et al., 2018a).

Table 2. Palemahan Perception (Source: Processed primary data, 2020)

\begin{tabular}{|c|l|c|c|c|c|c|c|c|}
\hline Variable & \multicolumn{1}{|c|}{ Question Items } & SD 1 & D 2 & A 3 & AG 4 & SA 5 & Amount (wght x freq) & Average \\
\hline \multirow{4}{*}{ Palemahan } & Divine activities & & & 5 & 20 & 57 & 380 & 4.63 \\
\cline { 2 - 9 } & Humanitarian Activities & & & 5 & 40 & 37 & 360 & 4.39 \\
\cline { 2 - 9 } & Guest room & & & 2 & 30 & 50 & 376 & 4.59 \\
\cline { 2 - 9 } & Manure and Gardens & & & 6 & 30 & 46 & 368 & 4.49 \\
\hline
\end{tabular}

Note: SD (strongly disagree); D (disagree); A (average); AG (agree); SA (strongly agree); wght (weight); Freq (frequency)

Table 3. Parahyangan Perception (Source: Processed data, 2020)

\begin{tabular}{|c|c|c|c|c|c|c|c|c|}
\hline Variable & Question Items & SD 1 & D 2 & A 3 & AG 4 & SA 5 & Amount (wght $\mathrm{x}$ freq) & Average \\
\hline \multirow{4}{*}{ Parahyangan } & Community activities in believing in God (prayer) & & & & 25 & 57 & 385 & 4.70 \\
\hline & Interacting with the community with cultural performances & & & & 45 & 37 & 365 & 4.45 \\
\hline & Introducing nature conservation through religious rituals & & & & 32 & 50 & 378 & 4.61 \\
\hline & \multicolumn{7}{|l|}{ Average } & 4.59 \\
\hline
\end{tabular}

Note: SD (strongly disagree); D (disagree); A (average); AG (agree); SA (strongly agree); wght (weight); Freq (frequency)

Table. 4 Pawongan Perception (Source: processed data, 2020)

\begin{tabular}{|c|l|c|c|c|c|c|c|c|}
\hline Variable & \multicolumn{1}{|c|}{ Question Items } & SD 1 & D 2 & A 3 & AG 4 & SA 5 & Amount (wght x freq) & Average \\
\hline \multirow{5}{*}{ Pawongan } & Accepting guests & & & 5 & 10 & 67 & 390 & 4.76 \\
\cline { 2 - 10 } & Means of Communication & & & 5 & 30 & 47 & 370 & 4.51 \\
\cline { 2 - 9 } & Keeping the relationship & & & 2 & 10 & 70 & 396 & 4.83 \\
\cline { 2 - 9 } & Social interaction & & & 6 & 20 & 56 & 378 & 4.61 \\
\hline
\end{tabular}

Note: SD (strongly disagree); D (disagree); A (average); AG (agree); SA (strongly agree); wght (weight); Freq (frequency) 
The cultural perception of the respondents' Parahyangan aspect gave the highest support of 4.70 (Table 3) from the existing indicators. This reflects how strong the belief in the values of believing in God which is shown by various rituals and cultural activities. This condition strengthens that tourism in Ubud is cultural tourism or has strong cultural roots. THK culture has an important role in building an order of life because it is integrated into religious activities and can affect the performance of organizations involved in the tourism industry (Astawa, 2013c; Astawa and Sudika, 2014; Astawa et al., 2016f). In Table 4, it is explained that the value of maintaining the relationship is 4.83 which means that the function of the designated place is culturally unchanged as a means of social interaction, it's just that the interaction has an increase in the allocation for guests who live with their families. Every guest who stays overnight is made part of the family so that it will grow a very strong kinship. This concept is one way to maintain relationships with consumers through their cultural values. This activity really supports sustainable tourism without sacrificing the existing culture in building tourism (Astawa et al., 2019d; Romão and Neuts, 2017).

The three cultural variables support the yard change activities that are carried out. These results provide reinforcement for the implementation of sustainable tourism that must contribute to the environment, economy and socio-culture (Romão and Neuts, 2017). The attributes of changes in the developed yard have been developed and include cultural elements in preserving nature and supporting the creation of sustainable tourism. The results of this study provide clarity for tourists and other tourism actors who must pay attention to and participate in preserving the existing culture. The World Tourism Organization (WTO, 2016), now the Nations World Tourism Organization (UNWTO), offers a definition of sustainable tourism development as "meeting the needs of today's tourists and hosting territories while protecting and enhancing opportunities for the future. It is considered to lead to the management of all resources in such a way that economic, social, and aesthetic needs are met while maintaining the integrity of culture, essential ecological processes, biological diversity and life support systems." (Liu et al., 2017; Chávez-Cortés and Maya, 2010). Basically the need to develop and manage these activities for the purpose of not sacrificing their resources, culture, or nature to achieve sustainability (Blancas et al., 2015). Therefore, the concept of sustainable tourism development can not only be considered as a holistically future-oriented system, but also an inward vision that includes all aspects related to the economy, environment, and society, towards achieving its goals (Sharpley, 2000).

\section{Acknowledgement}

The Indonesian government through the Directorate General of Research and Development of the Ministry of Research, Technology and Higher Education has funded this research so that it can be completed on time. The people of Ubud who have been willing to provide information in data collection.

\section{CONCLUSION}

The most changes in land use were in palemahan teba which was originally used as a breeding place, disposing of manure, and gardening due to the urgent need for lodging for tourists who want to know more about community life so that the land is used as a place to stay for tourists. Shifting the function of land in general will destroy the existing order of life, but in Ubud, the natural environment is still well preserved, reinforced by local cultural values. The quantitative results explain that land changes based on a culture of harmony have a positive impact on the economy, social, culture and environment. The results of this study support the development of sustainable tourism which is an important issue in today's era.

\section{REFERENCES}

Agyeiwaah, E., McKercher, B., \& Suntikul, W. (2017). Identifying core indicators of sustainable tourism: a path forward? Tourism Manage Perspect, 24, 26-33. https://doi.org/10.1016/j.tmp.2017.07.005

Astawa, I.P., Triyuni, N.N., \& Santosa, I.D.M.C. (2018a). Sustainable tourism and harmonious culture: a case study of cultic model at village tourism. In Journal of Physics, Conference Series, 953(1), 012057, IOP Publishing. https://iopscience.iop.org/article/10.1088/17426596/953/1/012057/meta

Astawa, P.I. (2013b). Ownership in the Perspective of Ethnomethodology at the Village Credit Institutional in Bali. Research Journal of Finance and Accounting, 4(8), 55-62. https://doi.org/10.7176/RJFA

Astawa, I.P., \& Sudika, P. (2015c). The Impact of Local Culture on Financial Performance in Property Firms in Bali. Asia-Pacific Management and Business Application, 3(2), 106-115. https://doi.org/10.21776/ub.apmba.2014.003.02.3

Astawa, I.P., Sukawati, T.G.R., \& Sugiartha, I.N.G. (2019d). Developing A Harmonious Culture-Based Sustainable Event Model In Bali Tourism Village. GeoJournal of Tourism and Geosites, 25(2), 446-462. https://doi.org/10.30892/gtg.25214-372

Astawa, I.P. (2018e). The Impact of Harmonious Culture and Entrepreneurship Training on Loan Repayment Performance at Microfinance in Indonesia. Asia-Pacific Management and Business Application, 6(3), 124-132. https://doi.org/10.21776/ub.apmba.2018.006.03.2

Astawa, I.P, Sukawati, T.G.R, Triyuni, N.N, \& Abdi, I.N. (2016f). Performance of Microfinance Institution in Harmony Cultural Perspective in Bali. Procedia-Social and Behavioral Sciences, 219, 113-120. https://doi.org/10.1016/j.sbspro.2016.04.051

Becken, S., \& Hay, J.E. (2007). Tourism and climate change: Risks and opportunities. Multilingual Matters. https://fokt.pw/tourism-andclimate-change.pdf

Blancas, F.J., Lozano-Oyola, M., González, M., \& Caballero, R. (2018). A dynamic sustainable tourism evaluation using multiple benchmarks. Journal of Cleaner Production, 174, 1190-1203. https://doi.org/10.1016/j.jclepro.2017.10.295

Bradley, P. (2018). Integrating sustainable development into economics curriculum: Acase study analysis and sector wide survey of barriers. Journal of Cleaner Production, 209, 333-352. https://doi.org/10.1016/j.jclepro.2018.10.184

Chávez-Cortés, M., \& Maya, J.A.A. (2010). Identifying and structuring values to guide the choice of sustainability indicators for tourism development. Sustainability, 2(9), 3074-3099. https://doi.org/10.3390/su2093074

Creswell, J.W., \& Clark, V.L.P. (2017). Designing and conducting mixed methods research. Sage publications. https://doc1.bibliothek.li/acd/FLMF050277.pdf

Dwi Atmanti, H. (2005). Human resource investment through education. Jurnal Dinamika Pembangunan (JDP), 2(1), 30-39. http://eprints.undip.ac.id/16864 
Font, X., \& Harris, C. (2004). Rethinking standards from green to sustainable. Annals of Tourism Research, 31(4), 986-1007. https://doi.org/10.1016/j.annals.2004.04.001

Glaser, B.G., \& Strauss, A.L. (2017). Discovery of grounded theory: Strategies for qualitative research. Routledge.

Gössling, S., \& Scott, D. (2008). Special Issue: Climate change and tourism: exploring destination vulnerability. Tourism Review International, 12(1). https://doi.org/10.3727/154427208785899975

Hofstede, G. (2007). A European in Asia. Asian Journal of Social Psychology, 10(1), 16-21. https://doi.org/10.1111/j.1467839X.2006.00206.X

Kapera, I. (2018). Sustainable tourism development efforts by local governments in Poland. Sustainable cities and society, 40, 581-588. https://doi.org/10.1016/j.scs.2018.05.001

Kimbu, A.N., \& Tichaawa, M.T. (2018). Sustainable Development Goals And Socio-Economic Development Through Tourism In Central Africa: Myth Or Reality? GeoJournal of Tourism and Geosites, 23(3), 780-796. https://doi.org/10.30892/gtg.23314-328

Liu, J., Nijkamp, P., Huang, X., \& Lin, D. (2017). Urban livability and tourism development in China: Analysis of sustainable development by means of spatial panel data. Habitat International, 68, 99-107. https://doi.org/10.1016/j.habitatint.2017.02.005

Mika, M. (2015). Sustainable tourism: a critique of the academic feasibility of the concept. Turyzm, 25(1), 9-17. https://www.ceeol.com/ search/article-detail?id=664464

Miles, M.B., Huberman, A.M., Huberman, M.A., \& Huberman, M. (1994). Qualitative data analysis: An expanded sourcebook. Sage Publications, pp. 336.

Murphy, P.E., \& Price, G.G. (2005). Tourism and sustainable development. Global Tourism, 3, 167-193. http://books.elsevier.com

Piketty, T. (2014). Capital in the Twenty-First Century. The Belknap Press of Harvard University Press Cambridge, Massachusetts London, England. https://dowbor.org/wp-content/uploads/2014/06/14Thomas-Piketty.pdf

Putri, A.E., Khadijah, U.L.S., \& Novianti, E. (2020). Community Empowerment In The Development Of Mangrove Tourism In Batu Karas Of Pangandaran, West Java. GeoJournal of Tourism and Geosites, 31(3), 972-978. https://doi.org/10.30892/gtg.31306-529

Rahmawati, P.I., Jiang, M., \& DeLacy, T. (2019). Framework for stakeholder collaboration in harnessing corporate social responsibility implementation in tourist destination to build community adaptive capacity to climate change. Corporate Social Responsibility and Environmental Management, 26(6), 1261-1271. https://doi.org/10.1002/csr.1745

Ranasinghe, R. (2019). Antecedents of Job Performance of Tourism Graduates: Evidence from State University-Graduated Employees in Sri Lanka. Journal of Tourism and Services, 10(18), 16-34. http://dx.doi.org/10.2139/ssrn.3517673

Rajiani, I., \& Pypłacz, P. (2018). National culture as modality in managing the carbon economy in Southeast Asia. Polish Journal of Management Studies, 18. https://doi.org/10.17512/pjms.2018.18.1.22

Romão, J., \& Neuts, B. (2017). Territorial capital, smart tourism specialization and sustainable regional development: Experiences from Europe. Habitat International, 68, 64-74. https://doi.org/10.1016/j.habitatint.2017.04.006

Sadguna, I.G.A.J., Komala, I.G.A.M.K., \& Shishido, K. (2020). Balinese Art Studios: The Learning Process of Art and Culture to Support Sustainable Tourism. International Journal of Applied Sciences in Tourism and Events, 4(1), 68-73. http://dx.doi.org/10.31940/ijaste.v4i1.1782

Schönborn, G., Berlin, C., Pinzone, M., Hanisch, C., Georgoulias, K., \& Lanz, M. (2019). Why social sustainability counts: The impact of corporate social sustainability culture on financial success. Sustainable Production and Consumption, 17, 1-10. https://doi.org/ 10.1016/j.spc.2018.08.008

Sharpley, R. (2000). Tourism and sustainable development: Exploring the theoretical divide. Journal of Sustainable tourism, 8(1), 1-19. https://doi.org/10.1080/09669580008667346

Sugiyono, P.D. (2010). Educational research methods. Quantitative Approach.Bandung Press, Indonesia.

Sukawati, T.G.R., \& Astawa, I.P. (2017). Improving performance by harmonious culture approach in internal marketing. Polish Journal of Management Studies, 16, 226-223.

Sumarmi, Kurniawati, E., \& Aliman, M. (2020). Community Based Tourism (Cbt) To Establish Blue Economy And Improve Public Welfare For Fishing Tourism Development In Klatak Beach, Tulungagung, Indonesia. GeoJournal of Tourism and Geosites, 31(3), 979-986. https://doi.org/10.30892/gtg.31307-530

Swarbrooke, J. (1998). Sustainable tourism management. CABI. Oxford.

Weaver, D.B. (2006). Sustainable tourism: Theory and practice. Routledge. https://books.google.co.id/books?

Wróblewski, Ł., \& Kasperek, A. (2019). Euroregion as an Entity Stimulating the Sustainable Development of the Cross-Border Market for Cultural Services in a City Divided by a Border. Sustainability, 11(8) 2232. https://doi.org/10.3390/su11082232

*** World Tourism Organization, (2016). UNWTO Tourism Highlights, 2016 Edition United.

*** Nations World Tourism Organization, Madrid, Spain. 